\title{
Knudsen Effusion Mass Spectrometry: Technique for Obtaining Useful Thermodynamic Information and for Studying Interesting Vaporization Chemistry
}

\author{
T.S. Lakshmi Narasimhan and R. Viswanathan ${ }^{*}$ \\ Fuel Chemistry Division, Chemistry Group, Indira Gandhi Centre for Atomic Research, Kalpakkam, Tamil Nadu 603 \\ 102, India
}

\begin{abstract}
Knudsen effusion mass spectrometry (KEMS) is a very powerful technique for studying the vaporization thermodynamics of inorganic systems at high temperatures. Although primarily one examines the vapor phase, information about condensed phases are also obtained through careful measurements and analysis of the results in accordance with the phase rule. In this paper, we have shown the capability of KEMS to yield information of practical importance and fundamental interest - essentially by drawing examples from the vaporization studies on some systems of tellurium, conducted in our laboratory for over two decades. The KEMS studies on M-Te (M = Fe, Cr, Ni, Mo, and Mn, the major components of stainless steel) and $\mathrm{Mn}-\mathrm{Te}-\mathrm{O}$ systems provided the pertinent information as to under what conditions the fission product Te can cause the chemical attack of 316 stainless steel cladding material used in fast breeder nuclear reactors. The study of $\mathrm{Mn}-\mathrm{Te}$ and $\mathrm{Mn}-\mathrm{Te}-\mathrm{O}$ systems also reveal the effects of condensed phase transitions on the vaporization behavior. Results of such studies are discussed in detail so that KEMS studies of this type will be undertaken more often in the future.
\end{abstract}

Keywords: Knudsen Effusion Mass Spectrometry (KEMS), thermochemistry, high temperature, vaporization, manganesetellurium-system, manganese-tellurium-oxygen system.

\section{INTRODUCTION}

High temperature chemistry plays an important role practically in all industries: metallurgical, nuclear, aerospace, lamp, and even electronic industry. To understand as well as to predict the behavior of materials at high temperatures, basic thermodynamic properties such as enthalpies and Gibbs free energies of relevant chemical equilibria are essential. This calls for the generation of thermodynamic data corresponding to both condensed- and vapor phases for as many substances as possible. Since any substance will vaporize if the temperature is high enough, vapor pressure measurements offer a convenient means of obtaining such information. No meaningful thermodynamic data, however, may be deducible even from a very reliable vapor pressure measurement if the actual vaporization process is not recognized. That is, if one does not know what the vapor phase is composed of. The characterization of vapors is best achieved by using the technique what is known as high temperature mass spectrometry.

Chupka and Inghram [1] did the pioneering work in the field of high temperature mass spectrometry. They studied the vaporization behavior of carbon filament and established that the major gaseous species in the vapor was trimeric

*Address correspondence to this author at the Fuel Chemistry Division, Chemistry Group, Indira Gandhi Centre for Atomic Research, Kalpakkam, Tamil Nadu 603 102, Índia; Tel: 91442748 0098; Fax: 91442748 0065;

E-mails: rvis@igcar.gov.in; tslak@igcar.gov.in carbon, $\mathrm{C}_{3}(\mathrm{~g})$. Subsequently, vaporization studies on various inorganic systems have been reported which include elements, intermetallic compounds, halides, oxides, hydroxides, carbides, nitrides, chalcogenides, and many ternary compounds. In most of these studies, evaporation of the condensed phase was done inside a container called Knudsen cell and the equilibrium vapor was allowed to effuse out through a small orifice on top of the Knudsen cell into the mass spectrometer. Thus the technique became known as Knudsen cell mass spectrometry (KCMS) or Knudsen effusion mass spectrometry (KEMS).

Let us consider some vaporization processes. The simplest is those of elements: almost all metals vaporize predominantly as atoms, and, in several cases, polymeric species of relatively smaller abundances are also generated. There are, however, several cases where it is not the monomers, but the polymers, which are the major species in the equilibrium vapor: tellurium (dimers); carbon (trimers); phosphorous (tetramers); selenium (pentamers and hexamers); and sulfur (octamers and hexamers).

We would now examine the relatively more complex vaporization processes, i.e., those of binary compounds. They involve production of several molecular species, homonuclear as well as heteronuclear. Furthermore, two kinds of vaporization reactions can occur: a) congruent; and b) incongruent

i $\operatorname{CsI}(\mathrm{s})=(\mathrm{CsI})_{\mathrm{i}}(\mathrm{g})$ where $\mathrm{i}=1$ (major); $2-4$ (minor) 
$3 \mathrm{CuCl}(\mathrm{s})=(\mathrm{CuCl})_{3}(\mathrm{~g})$

$\mathrm{Ga}_{2} \mathrm{X}_{3}(\mathrm{~s})=\mathrm{Ga}_{2} \mathrm{X}(\mathrm{g})+\mathrm{X}_{2}(\mathrm{~g})$ where $\mathrm{X}=\mathrm{S}$ or $\mathrm{Se}$

$\mathrm{Li}_{3} \mathrm{~N}(\mathrm{~s})=3 \mathrm{Li}(\mathrm{g})+0.5 \mathrm{~N}_{2}(\mathrm{~g})$

$\operatorname{MnTe}(\mathrm{s})=\operatorname{Mn}(\mathrm{g})+\alpha \mathrm{Te}(\mathrm{g})+(1-\alpha) / 2 \mathrm{Te}_{2}(\mathrm{~g})$

$\mathrm{Mo}_{3} \mathrm{Te}_{4}(\mathrm{~s})=3 \mathrm{Mo}(\mathrm{s})+2 \mathrm{Te}_{2}(\mathrm{~g})$

$3 \mathrm{MoTe}_{2}(\mathrm{~s})=\mathrm{Mo}_{3} \mathrm{Te}_{4}(\mathrm{~s})+\mathrm{Te}_{2}(\mathrm{~g})$

$4 \mathrm{GaSe}(\mathrm{s})=\mathrm{Ga}_{2} \mathrm{Se}_{3}(\mathrm{~s})+\mathrm{Ga}_{2} \mathrm{Se}(\mathrm{g})$

Reactions (1) to (5) represent congruent vaporization reactions: that is, the atom fractions of the elements in the vapor and the condensed phases are same. The first two reactions correspond to molecular vaporization of the condensed phase to predominantly monomers (reaction 1 ) or trimers (reaction 2); reactions (4) and (5) correspond to decomposition of the condensed phases to gaseous elements; and reaction (3) corresponds to evaporation to a gaseous element and a molecular species consisting of both elements. Congruent vaporization does not make the condensed phase unstable, and therefore, even under dynamic conditions (where the equilibrium vapor can effuse out or get transported out), vaporization will continue without any change in the composition until the exhaustion of the whole condensed phase.

Reactions (6) to (8) represent incongruent vaporization reactions: that is, the atom fractions of the two elements in the vapor and the condensed phases are not same. Consequently a new condensed phase gets generated (element in reaction 6 and compounds in reactions 7 and 8). The gaseous species are elements in reaction (6) and (7), and a heteronuclear species in reaction (8).

Gaseous species with unusual oxidation states were also identified: $\mathrm{LiO}(\mathrm{g}), \mathrm{Li}_{3} \mathrm{O}(\mathrm{g})$, and $\mathrm{Li}_{2} \mathrm{O}_{2}(\mathrm{~g})$ in the equilibrium vapor over $\mathrm{Li}_{2} \mathrm{O} ; \mathrm{Ba}_{2} \mathrm{O}(\mathrm{g})$ and $\mathrm{Ba}_{2} \mathrm{O}_{3}(\mathrm{~g})$ over $\mathrm{BaO} ; \mathrm{AlO}(\mathrm{g})$, $\mathrm{Al}_{2} \mathrm{O}(\mathrm{g})$, and $\mathrm{Al}_{2} \mathrm{O}_{2}(\mathrm{~g})$ over $\mathrm{Al}_{2} \mathrm{O}_{3}$.

Why would anyone bother about the gaseous species that are present only in small proportions? It is because what is a minor species at a certain temperature may become a major species at higher temperatures. While explaining the increasing complexity of the vapor phase with increasing temperature, Brewer [2] has remarked: "at high temperatures anything goes!". The extent of research conducted by using KEMS is so enormous that numerous review articles have been periodically written, the notable ones being those by Drowart and his coworkers [3-5], Grimley [6], Gingerich [7], and Hilpert [8]. The review articles and the references quoted therein would reveal the potential and the problem areas of the high temperature mass spectrometric technique. If the greatest potential of KEMS lies in its ability to detect gaseous species in a very large dynamic range of partial pressures, the nagging problem in the conversion of ion intensities into partial pressures lies in the elucidation of the fragmentation processes and in the use of appropriate electronimpact ionization cross sections. Drowart et al. [9] have very recently critically assessed some of these aspects, paying special attention to the influence of ionization cross sections.

We do not intend to dwell in this article those fundamental aspects of KEMS which were all so well discussed in the reviews referred here. Instead, we intend to focus our attention on just two aspects based almost entirely on the KEMS studies conducted in authors' laboratory: 1) what kind of useful thermodynamic information was obtained with the KEMS studies on binary and ternary systems of tellurium; and 2) what kind of insight we could obtain into the interesting vaporization chemistry associated with the condensed phase transitions on two systems involving tellurium and manganese, one the binary $\mathrm{Mn}-\mathrm{Te}$, and the other, ternary Mn-Te-O.

Our interest on the systems of tellurium stemmed from the fact that tellurium is a volatile and reactive element generated during the nuclear fission and is believed to cause corrosion of the fuel-cladding, especially in the case of mixed oxide fuelled fast breeder nuclear reactors [10]. Clad corrosion is one of the factors that would limit the life of a fuel element in the reactor. By means of vaporization studies on binary telluride phases (M-Te), where $M$ refers to the components of the stainless steel (SS) cladding $\mathrm{Fe}, \mathrm{Cr}, \mathrm{Ni}$, $\mathrm{Mn}, \mathrm{Mo}$, the threshold chemical potentials of tellurium for the formation of the most metal-rich tellurides on each binary system were deduced. The phase boundaries of the non-stoichiometric telluride phases were also determined by using KEMS. Amongst the nuclear fuels, the uranium plutonium mixed oxide fuel provides the most favorable environment (through its oxygen potential) for raising the tellurium activity in the fuel-clad gap to a level higher than those required for the attack of SS by tellurium - by facilitating the decomposition of cesium telluride, an otherwise stable compound formed by interaction between tellurium and cesium one of the major fission products. Thus, thermodynamic information on the ternary oxide phases involving tellurium and SS components are also of relevance to Fuel Clad Chemical Interactions (FCCI). We first took up the study of the Mn-Te-O ternary system following our finding that amongst the binary tellurides, the least threshold tellurium potential was for manganese telluride.

Vaporization chemistry associated with condensed phase transitions can be quite fascinating and interesting. During the course of a phase transition in a congruently vaporizing system, vaporization will become incongruent and this change from congruent to non-congruent vaporization might cause unusual and counterintuitive effects. Such effects can be best investigated by KEMS. It was thirty three years ago that anomalies in the vaporization behavior during condensed phase transitions have been first reported. Roberts and Searcy [11] observed a $50 \%$ increase in the partial pressure of $\mathrm{Ga}_{2} \mathrm{~S}(\mathrm{~g})$ over $\mathrm{Ga}_{2} \mathrm{~S}_{3}(\mathrm{~s})$ when the temperature was decreased from $1230 \mathrm{~K}$ to $1203 \mathrm{~K}$ - quite contrary to the normal $50 \%$ decrease in partial pressures for a $25 \mathrm{~K}$ decrease in other temperature ranges. The topic of effect of phase transitions on vaporization behavior has been the subject of sustained research by Edwards and his coworkers [12-19] for about two decades. Although not all these studies were performed by KEMS, it is readily understandable that KEMS can be an excellent tool for such studies. While the study of binary and ternary systems of tellurium met our primary objective of obtaining a better understanding of FCCI in fast reactors, the study of $\mathrm{Mn}-\mathrm{Te}$ and $\mathrm{Mn}-\mathrm{Te}-\mathrm{O}$ systems provided some insight into the fundamental aspects of the interesting vaporization chemistry associated with the condensed phase transitions. 
We discuss below in detail the two aspects of KEMS, one of practical importance in nuclear technology, and the other more of fundamental interest, both primarily based on the KEMS studies performed in the authors' laboratory.

\section{EXPERIMENTAL}

The vaporization experiments were carried out by using a VG micromass 30 BK Knudsen effusion mass spectrometer. Each experiment involved heating by electron bombardment of a known aliquot of a sample, taken in an alumina Knudsen cell (lined with platinum in experiments involving Mn-Te-O samples) and placed inside a molybdenum cup. The temperatures were measured by a chromel-alumel thermocouple inserted through the base of the molybdenum cup and touching the base of the Knudsen cell. The molecular beam effusing out of the Knudsen cell was ionized by electrons emitted from a tungsten filament. The ions produced were accelerated to $6 \mathrm{kV}$, mass analyzed by a $90^{\circ}$ sector magnetic analyzer, and detected by a secondary electron multiplier/ Faraday cup. The thermocouple was calibrated against the melting point of silver and the electron energy scale was calibrated using the first ionization energies of $\mathrm{In}^{+}, \mathrm{Hg}^{+}, \mathrm{Ag}^{+}, \mathrm{Ar}^{+}$and $\mathrm{He}^{+}$.

\section{RESULTS AND DISCUSSION}

\section{Threshold Tellurium Potentials for Formation of Metal- rich $\mathrm{MTe}_{\mathrm{x}}$ on SS 316}

The samples used with the objective of obtaining information related to threshold tellurium potentials for the formation of metal-rich telluride phases on SS clad corresponded to the two phase mixtures $\mathrm{M}(\mathrm{s})+\mathrm{MTe}_{\mathrm{x}}(\mathrm{s})$. The ions observed in the mass spectrum of the equilibrium vapor over these samples were $\mathrm{Te}^{+}$and $\mathrm{Te}_{2}{ }^{+}$for $\mathrm{M}=\mathrm{Fe}, \mathrm{Cr}, \mathrm{Ni}$, and Mo while they were $\mathrm{Mn}^{+}$and $\mathrm{Te}^{+}$for $\mathrm{M}=\mathrm{Mn}$. The ion intensities were measured as a function of temperature usually at two electron impact energies, one at high $(>30$ $\mathrm{eV})$ and the other at low $(<12 \mathrm{eV})$. Except the sample of the $\mathrm{Mn}-\mathrm{Te}$ system whose vapor phase was dominated by the metallic atoms, $\mathrm{Mn}(\mathrm{g})$, all other samples were characterized by the vapor phase composed entirely of $\mathrm{Te}_{\mathrm{i}}(\mathrm{g})(\mathrm{i}=1$ and 2$)$, the proportion of $\mathrm{Te}(\mathrm{g})$, the monomer, varying from $\sim 2 \%$ over $\left(\mathrm{Fe}+\mathrm{FeTe}_{\mathrm{x}}\right)$ to $\sim 50 \%$ over $\left(\mathrm{Cr}+\mathrm{CrTe}_{\mathrm{x}}\right)$. The identification of the gaseous species was performed by determining the appearance potentials from and examining the nature of the breaks in the ionization efficiency curves for the ions $\mathrm{Te}_{\mathrm{i}}^{+}$(plot of ion intensity as a function of electron impact energy) and comparing them with the known values of ionization potential for $\mathrm{Te}(\mathrm{g})$ and the dissociation energy of $\mathrm{Te}_{2}(\mathrm{~g})$. The partial pressures of the gaseous species were deduced by appropriate pressure calibration procedure: performing vaporization runs with elemental tellurium, the value of $\mathrm{p}\left(\mathrm{Te}_{2}\right)$ over which is known (and elemental manganese in situ in the case of Mn-Te samples).

The equations employed are:

$\mathrm{p}\left(\mathrm{Te}_{2}\right)=\mathrm{k}\left(\mathrm{Te}_{2}\right) \mathrm{I}\left(\mathrm{Te}_{2}{ }^{+}\right) \mathrm{T}$

where $\mathrm{k}\left(\mathrm{Te}_{2}\right)$ is the pressure calibration constant for $\mathrm{Te}_{2}(\mathrm{~g})$

$\mathrm{k}\left(\mathrm{Te}_{2}\right)=\left\{\mathrm{p}^{\mathrm{o}}\left(\mathrm{Te}_{2}\right) /\left[\mathrm{I}^{\mathrm{o}}\left(\mathrm{Te}_{2}{ }^{+}\right) \mathrm{T}\right]\right\}$ where the superscript ' $\mathrm{o}$ ' denotes the values of known $\left[\mathrm{p}^{\mathrm{O}}\left(\mathrm{Te}_{2}\right)\right]$ and measured $\mathrm{I}^{\mathrm{O}}\left(\mathrm{Te}_{2}{ }^{+}\right)$for elemental tellurium

$\mathrm{p}(\mathrm{Mn})=\mathrm{k}(\mathrm{Mn}) \mathrm{I}\left(\mathrm{Mn}^{+}\right) \mathrm{T}$

where $\mathrm{k}(\mathrm{Mn})$ is the pressure calibration constant for $\mathrm{Mn}(\mathrm{g})$

$\mathrm{k}(\mathrm{Mn})=\left\{\mathrm{p}^{\mathrm{o}}(\mathrm{Mn}) /\left[\mathrm{I}^{\mathrm{o}}\left(\mathrm{Mn}^{+}\right) \mathrm{T}\right]\right\}$

where the superscript ' $\mathrm{o}$ ' denotes the values of known $\mathrm{p}^{\circ}(\mathrm{Mn})$ and measured I $\left(\mathrm{Mn}^{+}\right)$for elemental manganese.

$\mathrm{p}(\mathrm{Te})=\mathrm{k}(\mathrm{i}) \mathrm{I}\left(\mathrm{Te}^{+}\right) \mathrm{T}\left\{\sigma(\mathrm{i}) \gamma\left(\mathrm{i}^{\dagger}\right) \eta\left(\mathrm{i}^{\dagger}\right)\right\} /\left\{\sigma(\mathrm{Te}) \gamma\left(\mathrm{Te}^{+}\right) \eta\left(\mathrm{Te}^{+}\right)\right\}(13)$

where ' $\mathrm{i}$ ' is the reference species or $\mathrm{i}^{+}$is the reference ion: $\mathrm{Mn}$ for $\mathrm{Mn}-\mathrm{Te}$ system and $\mathrm{Te}_{2}$ for other systems, $\sigma$ is the relative ionization cross section for the gaseous species i or $\mathrm{Te}, \gamma$ the relative detector response for the ion $\mathrm{i}^{+}$or $\mathrm{Te}^{+}, \eta$ is the relative abundance of the isotope of the ion whose intensity was measured.

References [20-24] give the p-T relations for the species in the equilibrium vapor over $\left(\mathrm{M}+\mathrm{MTe}_{\mathrm{x}}\right)$. The values of $\mathrm{p}(\mathrm{Te})$ and $\mathrm{p}\left(\mathrm{Te}_{2}\right)$ obtained over $\left(\mathrm{M}+\mathrm{MTe}_{\mathrm{x}}\right)(\mathrm{M}=\mathrm{Fe}, \mathrm{Cr}, \mathrm{Ni}$, and $\mathrm{Mo}$ ) ranged from $\sim 0.02$ to $1 \mathrm{~Pa}$ and corresponded to the temperature range from 820 to $1285 \mathrm{~K}$. The reliability of the $\mathrm{p}\left(\mathrm{Te}_{\mathrm{i}}\right) \mathrm{s}$ measured by us was revealed by a) the consistency of the values of the equilibrium constants for the dissociation equilibrium $\mathrm{Te}_{2}(\mathrm{~g})=2 \mathrm{Te}(\mathrm{g})$ obtained from these results; and b) the consistency with those reported in the literature at higher temperatures from 1195 to $1467 \mathrm{~K}$. Reference [25] gives the equilibrium constant temperature relation recommended by us for the dissociation equilibrium $\mathrm{Te}_{2}(\mathrm{~g})=$ $2 \mathrm{Te}(\mathrm{g})$.

The usefulness of the $\mathrm{p}\left(\mathrm{Te}_{\mathrm{i}}\right)$ data, as mentioned already, lie in the calculation of the threshold tellurium potential $\Delta \mu_{\text {thr }}(\mathrm{Te})$ for the formation of $\mathrm{MTe}_{\mathrm{x}}$ on the SS clad of fast reactors. Since $\mathrm{Te}_{2}(\mathrm{~g})$ is the major vapor species over elemental tellurium, the thermodynamic activity of tellurium at any temperature $\mathrm{T}$ is computed as:

$\mathrm{a}(\mathrm{Te})=\left\{\left[\mathrm{p}\left(\mathrm{Te}_{2}, \mathrm{~g}\right)\right.\right.$ over $\left.\mathrm{M}+\mathrm{MTe}_{\mathrm{x}}\right] /\left[\mathrm{p}^{\mathrm{o}}\left(\mathrm{Te}_{2}, \mathrm{~g}\right)\right.$ over elemental tellurium] $\}^{1 / 2}$

$\Delta \mu_{\text {thr }}(\mathrm{Te})=\mathrm{R} \cdot \mathrm{T} \cdot \ln [\mathrm{a}(\mathrm{Te})]$

Although our measurements were all performed with free metal present as a separate phase along with its telluride phase, the results can be utilized for the SS clad, if thermodynamic activities of the metals are known. The equation for tellurium potential calculation in the case of SS clad is:

$\Delta \mu_{\text {thr }}(\mathrm{Te})=\mathrm{R} T\left[\ln \mathrm{a}(\mathrm{Te}),\left(\mathrm{M}+\mathrm{MTe}_{\mathrm{x}}\right)-(1 / \mathrm{x}) \ln \mathrm{a}(\mathrm{M}, \mathrm{SS})\right]$

Since $\mathrm{p}\left(\mathrm{Te}_{2}\right)$ over $\left(\mathrm{Mn}+\mathrm{MnTe}_{\mathrm{x}}\right)$ was not measurable, it was computed by using the measured $\mathrm{p}(\mathrm{Te})$ and the dissociation constant $\mathrm{K}$ (dis $\left.\mathrm{Te}_{2}, \mathrm{~g}\right)$ :

$\left.\mathrm{p}\left(\mathrm{Te}_{2}\right)=[\mathrm{p}(\mathrm{Te})]^{2} / \mathrm{K}\left(\operatorname{dis~Te}_{2}, \mathrm{~g}\right)\right]$

The values of a(Te) and $\Delta \mu_{\text {thr }}(\mathrm{Te})$ computed by using the equations given above are listed in Table 1. Although the chemical compositions of SS 316 decrease in the order $\mathrm{Fe}>$ $\mathrm{Cr}>\mathrm{Ni}>\mathrm{Mo} \geq \mathrm{Mn}$, the threshold tellurium potential for the formation of the most metal-rich telluride on SS 316 is the 
Table 1. Threshold Tellurium Potentials for the Formation $\mathrm{MTe}_{\mathrm{x}}$ on SS Clad

\begin{tabular}{|c|c|c|c|c|c|c|c|c|c|}
\hline \multirow[b]{2}{*}{$\mathbf{M T e}_{\mathrm{x}}{ }^{\mathrm{a}}$} & \multicolumn{3}{|c|}{$900 \mathrm{~K}$} & \multicolumn{3}{|c|}{$1000 \mathrm{~K}$} & \multicolumn{3}{|c|}{$1100 \mathrm{~K}$} \\
\hline & $\begin{array}{c}a(T e) \text { in } \\
M+M T e_{x}\end{array}$ & $\begin{array}{l}a(M) \text { in } \\
S 316^{b}\end{array}$ & $\begin{array}{c}\Delta \mu_{\mathrm{thr}}(\mathrm{Te}) \\
\mathrm{kJ} \cdot \mathrm{mol}^{-1}\end{array}$ & $\begin{array}{c}\mathbf{a}(\mathrm{Te}) \text { in } \\
\mathrm{M}+\mathrm{MTe}_{\mathrm{x}}\end{array}$ & $\begin{array}{l}a(M) \text { in } \\
\text { SS } 316\end{array}$ & $\begin{array}{c}\Delta \mu_{\text {thr }}(\mathrm{Te}) \\
\mathrm{kJ} \cdot \mathrm{mol}^{-1}\end{array}$ & $\begin{array}{c}\mathbf{a}(\mathrm{Te}) \text { in } \\
\mathbf{M}+\mathrm{MTe}_{\mathbf{x}}\end{array}$ & $\begin{array}{l}a(M) \text { in } \\
\text { SS } 316\end{array}$ & $\begin{array}{c}\Delta \mu_{\text {thr }}(\mathrm{Te}) \\
\mathrm{kJ} \cdot \mathrm{mol}^{-1}\end{array}$ \\
\hline $\mathrm{FeTe}_{0.811}$ & $1.1 \times 10^{-2}$ & $8.0 \times 10^{-1}$ & -31.6 & $2.1 \times 10^{-2}$ & $8.5 \times 10^{-1}$ & -30.7 & $3.4 \times 10^{-2}$ & $9.0 \times 10^{-1}$ & -29.6 \\
\hline $\mathrm{CrTe}_{1.029}$ & $1.5 \times 10^{-4}$ & $3.2 \times 10^{-1}$ & -57.3 & $4.9 \times 10^{-4}$ & $3.1 \times 10^{-1}$ & -54.0 & $1.2 \times 10^{-3}$ & $3.1 \times 10^{-1}$ & -50.6 \\
\hline $\mathrm{NiTe}_{0.634}$ & $9.0 \times 10^{-4}$ & $5.0 \times 10^{-1}$ & -44.3 & $2.1 \times 10^{-3}$ & $6.1 \times 10^{-1}$ & -44.9 & $3.7 \times 10^{-3}$ & $7.3 \times 10^{-1}$ & $-46.2^{\mathrm{c}}$ \\
\hline $\operatorname{MoTe}_{1.1}$ & $2.4 \times 10^{-3}$ & $8.9 \times 10^{-2}$ & -28.6 & $6.6 \times 10^{-3}$ & $4.0 \times 10^{-2}$ & -17.4 & $1.5 \times 10^{-2}$ & $2.1 \times 10^{-2}$ & -6.3 \\
\hline $\operatorname{MnTe}_{0.8}$ & $1.9 \times 10^{-7}$ & $7.5 \times 10^{-3}$ & -70.0 & $9.4 \times 10^{-7}$ & $1.4 \times 10^{-2}$ & -71.4 & $3.5 \times 10^{-6}$ & $2.5 \times 10^{-2}$ & -72.8 \\
\hline
\end{tabular}

${ }^{a}$ The value of $\mathrm{x}$ in $\mathrm{MTe}_{\mathrm{x}}$ were obtained from references [26] $\left(\mathrm{FeTe}_{\mathrm{x}}\right)$, [21] $\left(\mathrm{CrTe}_{\mathrm{x}}\right)$, [27] $\left(\mathrm{NiTe}_{\mathrm{x}}\right)$, [28] $\left(\mathrm{MoTe}_{\mathrm{x}}\right)$, and [24] $\left(\mathrm{MnTe}_{\mathrm{x}}\right)$.

${ }^{\mathrm{b}}$ The values of $\mathrm{a}(\mathrm{M})$ in SS 316 were taken from reference [29].

${ }^{c} \mathrm{x}=0.587$ in $\mathrm{NiTe}_{\mathrm{x}}$ at $1100 \mathrm{~K}$ (from reference [27]).

least for $\mathrm{Mn}$ and the highest for Mo, and decreases in the order $\mathrm{Mo}>\mathrm{Fe}>\mathrm{Ni}>\mathrm{Cr}>\mathrm{Mn}$.

\section{Threshold Tellurium Potential for the Formation of Ternary Mn-Te-O Phases on SS 316}

Our KEMS study of the ternary Mn-Te-O system [30-32] led to the determination of the phase diagram at $950 \mathrm{~K}$ [30] (reproduced in Fig. (1), vaporization behavior of four three phase regions around the $\mathrm{MnO}-\mathrm{TeO}_{2}$ binary line [31], and thermodynamic data for these ternary phases [32]. Furthermore, the threshold tellurium potentials $\Delta \mu_{\text {thr }}$ (Te) required for the formation of these ternary phases $\left(\mathrm{Mn}_{\mathrm{z}} \mathrm{Te}_{\mathrm{x}} \mathrm{O}_{\mathrm{y}}\right)$ on SS 316 clad of mixed oxide (U-Pu) fuelled fast reactors were also deduced [32]. The equation employed for this purpose was:

$\Delta \mu_{\text {thr }}(\mathrm{Te})=\left[\Delta_{\mathrm{f}} \mathrm{G}^{\mathrm{O}}\left(\mathrm{Mn}_{\mathrm{z}} \mathrm{Te}_{\mathrm{x}} \mathrm{O}_{\mathrm{y}}\right)-\mathrm{z} \cdot \mathrm{R} \cdot \mathrm{T} \cdot \ln \mathrm{a}(\mathrm{Mn}, \mathrm{SS})-\right.$ $(\mathrm{y} / 2) \Delta \mu\left(\mathrm{O}_{2}\right.$, fuel $\left.)\right] / \mathrm{x}$

Where $\Delta_{\mathrm{f}} \mathrm{G}^{\mathrm{O}}\left(\mathrm{Mn}_{\mathrm{z}} \mathrm{Te}_{\mathrm{x}} \mathrm{O}_{\mathrm{y}}\right)$ is the Gibbs energy of formation of the ternary phases [31], $\Delta \mu\left(\mathrm{O}_{2}\right.$, fuel) is the oxygen potential of the mixed oxide fuel at $\mathrm{T}$ and at a given $\mathrm{O} /(\mathrm{U}+\mathrm{Pu})$ ratio and $\mathrm{a}(\mathrm{Mn})$ is the activity of manganese in SS 316 . Table 2 gives the results pertinent to the four ternary $\mathrm{Mn}-\mathrm{Te}-\mathrm{O}$ phases at $\mathrm{T}=900 \mathrm{~K}$.

The phase $\mathrm{Mn}_{3} \mathrm{TeO}_{6}$ which can be placed on the $\mathrm{MnO}$ $\mathrm{TeO}_{3}$ binary line (3:1) require the least threshold potential for the formation compared to that for the other three ternary phases $\mathrm{Mn}_{6} \mathrm{Te}_{5} \mathrm{O}_{16}, \mathrm{MnTeO}_{3}$, and $\mathrm{Mn}_{2} \mathrm{Te}_{3} \mathrm{O}_{8}$, all of which can be placed on the $\mathrm{MnO}^{-} \mathrm{TeO}_{2}$ binary line (1.2: 1, 1:1, and $0.67: 1$, respectively). Comparison of $\Delta \mu_{\mathrm{thr}}(\mathrm{Te})$ values given in Tables 1 and 2 show that the values for $\mathrm{Mn}_{3} \mathrm{TeO}_{6}$ at $\mathrm{O} /(\mathrm{U}+\mathrm{Pu})=2.0004$ are more negative than that for tellurides of $\mathrm{Fe}, \mathrm{Ni}$, and Mo indicating the greater probability of the formation of the ternary phase than the binary tellurides when the fuel becomes even slightly hyperstoichiometric.

Having computed the $\Delta \mu_{\text {thr }}(\mathrm{Te})$ values for binary tellurides and ternary $\mathrm{Mn}-\mathrm{Te}-\mathrm{O}$ phases, it was of importance to find out the tellurium potentials that can exist in the fuelclad gap $\Delta \mu_{\mathrm{f}-\mathrm{c} \mathrm{gap}}(\mathrm{Te})$ because only if $\Delta \mu_{\mathrm{f}-\mathrm{c} \mathrm{gap}}(\mathrm{Te})>\Delta \mu_{\mathrm{thr}}(\mathrm{Te})$ can the clad get attacked by the fission product tellurium. Our calculation of $\Delta \mu_{\mathrm{f}-\mathrm{c} \text { gap }}(\mathrm{Te})$ (described in reference 21) showed that such a situation exists if the fuel becomes hyperstoichiometric, that is when $\mathrm{O} /(\mathrm{U}+\mathrm{Pu})$ ratio $>2$. Fig. (2) shows a comparison of $\Delta \mu_{\mathrm{thr}}(\mathrm{Te})$ and $\Delta \mu_{\mathrm{f}-\mathrm{c} \mathrm{gap}}(\mathrm{Te})$ values.

\section{Thermodynamic Information on the Non-Stoichiometric} Telluride Phases

It is evident from equation (16) that the value of $\mathrm{x}$ in $(\mathrm{M}+\mathrm{MTe})$, which represents the metal-rich boundary composition of the $\mathrm{MTe}_{\mathrm{x}}$ phase, is necessary for calculation of threshold tellurium potential. This information was also obtained by us through KEMS (except for $\mathrm{NiTe}_{\mathrm{x}}$ ) by making use of the fact that the vaporization from the Knudsen effusion cell involved the preferential loss of $\mathrm{Te}$ (from the metal-rich telluride phases of $\mathrm{Fe}, \mathrm{Cr}, \mathrm{Ni}, \mathrm{Mo}$ ) and $\mathrm{Mn}$ (Mn-rich telluride phase). Continuous vaporization of ( $\mathrm{Mn}+$ $\mathrm{MnTe}_{\mathrm{x}}$ ) biphasic sample caused the composition change progressively towards Te-rich side and hence the sample traversed through the two phase field of $\left(\mathrm{Mn}+\mathrm{MnTe}_{\mathrm{x}}\right)$ into the single phase manganese monotelluride phase by crossing the Mn-rich boundary of the latter. By monitoring the ion intensity of both $\mathrm{Mn}^{+}$and $\mathrm{Te}^{+}$all through the experiment and correlating it to the total mass loss (through Hertz-Knudsen equation), the Mn-rich boundary of the manganese monotelluride phase was determined [24]. In the case of other M-Te systems, the starting sample was either the adjacent two phase field ( $\mathrm{Fe}$, and $\mathrm{Mo}$ ) or the adjacent single phase field (Cr). Continuous vaporization of such samples caused the composition change progressively towards M-rich side and the experiments were continued until it could be ascertained that the sample reached the two phase field of $(\mathrm{M}$ $+\mathrm{MTe}_{\mathrm{x}}$ ) after crossing the M-rich boundary of the telluride phase. By monitoring the ion intensity of $\mathrm{Te}^{+}$and/ or $\mathrm{Te}_{2}{ }^{+}$all through the experiment and correlating it to the total mass loss (through Hertz-Knudsen equation), the M-rich boundary of the telluride phases were determined. References 21 (for $\mathrm{CrTe}_{\mathrm{x}}$ ), 26 (for $\mathrm{FeTe}_{\mathrm{x}}$ ), and $28\left(\right.$ for $\mathrm{MoTe}_{\mathrm{x}}$ ) give the details. In the case of $\mathrm{NiTe}_{\mathrm{x}}$, the values read off from the phase diagram given by Klepp and Komarek [27] were employed. The formulas given in Table $\mathbf{1}$ correspond to the phase boundary compositions deduced as mentioned above. Phase boundaries of some Te-rich telluride phases were also determined by us as part of our programme to deduce thermodynamic properties of other phases in the $\mathrm{M}-\mathrm{Te}$ systems: $\mathrm{CrTe}_{(4-y)}, \mathrm{CrTe}_{3}, \mathrm{Cr}_{5} \mathrm{Te}_{8}$ in the $\mathrm{Cr}-\mathrm{Te}$ system [34] and $\mathrm{MnTe}_{2}$ in the Mn-Te system [35]. In the Cr-Te system, one of our experiments [34] consisted of continuous measurements for $\sim 90 \mathrm{~h}$ which resulted in the composition change from 80.0 at. $\%$ Te (the most Te-rich two phase 


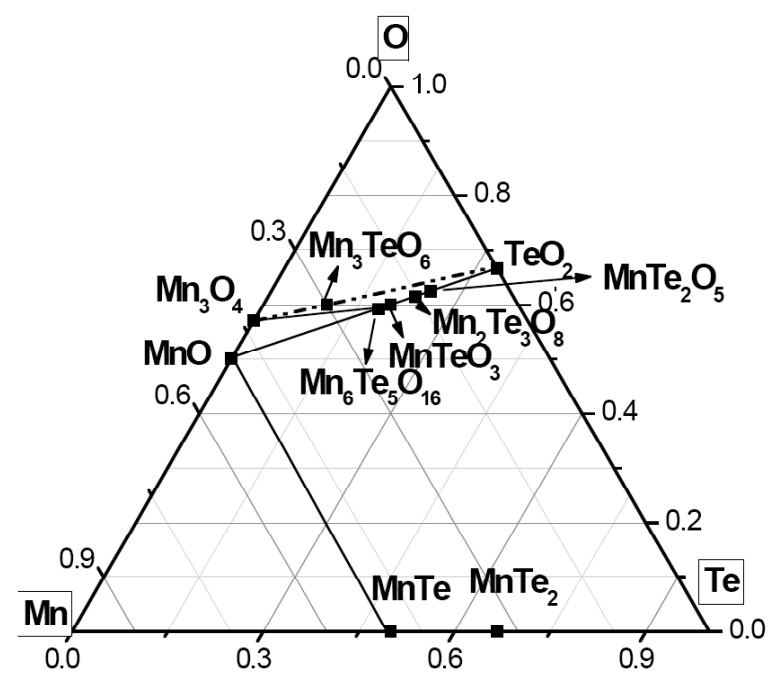

(a)

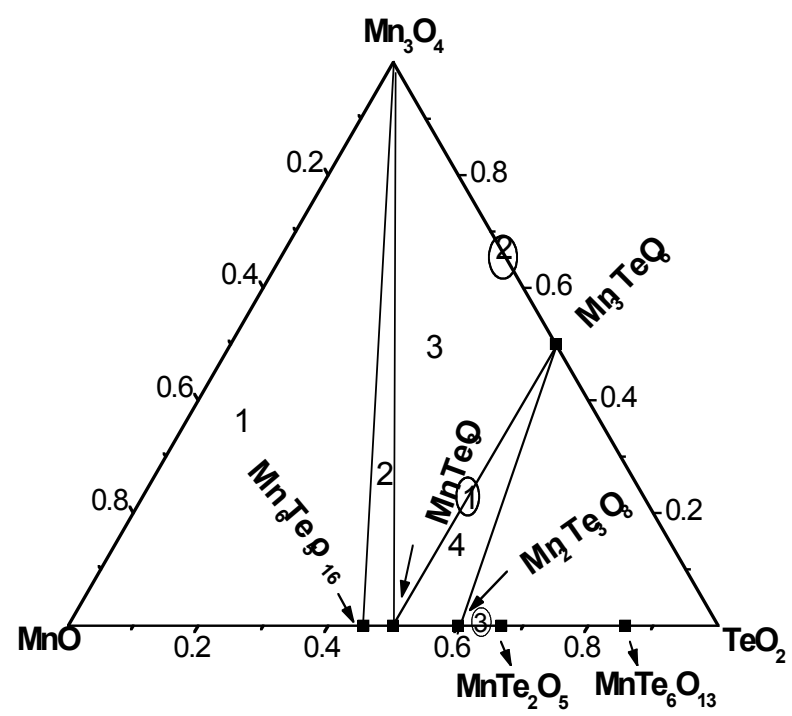

(b)

Fig. (1). Phase diagram of Mn-Te-O system at $950 \mathrm{~K}$ reproduced from Reference 30. (a) elements on the vertices; (b) binary oxide phases on the vertices - showing more clearly the three-phase regions $\left(\mathrm{Mn}_{3} \mathrm{O}_{4}+\mathrm{MnTeO}_{3}+\mathrm{Mn}_{3} \mathrm{TeO}_{6}\right)$, and $\left(\mathrm{MnTeO}_{3}+\mathrm{Mn}_{3} \mathrm{TeO}_{6}+\mathrm{Mn}_{2} \mathrm{Te}_{3} \mathrm{O}_{8}\right)$ separated by the binary line (comprising the ternary phases $\mathrm{MnTeO}_{3}$ and $\mathrm{Mn}_{3} \mathrm{TeO}_{6}$ ).

Table 2. Threshold Tellurium Potentials for the Formation of $\mathrm{Mn}_{\mathrm{z}} \mathrm{Te}_{\mathrm{x}} \mathrm{O}_{\mathrm{y}}$ on SS at $\mathrm{T}=900 \mathrm{~K}$. a(Mn) $=7.5 \mathrm{x} 10^{-3}$

\begin{tabular}{|c|c|c|c|c|c|}
\hline \multirow{2}{*}{$\begin{array}{c}\mathrm{O} /(\mathbf{U}+\mathbf{P u}) \\
\text { Ratio, Fuel }\end{array}$} & \multirow{2}{*}{$\begin{array}{c}\Delta \mu\left(O_{2}, \text { Fuel }\right)^{\mathrm{a}} \\
\left(\mathrm{kJ} \cdot \mathrm{mol}^{-1}\right)\end{array}$} & \multicolumn{4}{|c|}{$\Delta \mu_{\text {thr }}(\mathrm{Te}) /\left(\mathrm{k} \mathrm{J} \cdot \mathrm{mol}^{-1}\right)$ for formation of $\mathrm{Mn}_{\mathrm{z}} \mathrm{Te}_{\mathrm{x}} \mathrm{O}_{\mathrm{y}}$ on SS clad of U-Pu mixed oxide fuelled fast Reactor } \\
\hline & & $\mathrm{Mn}_{6} \mathrm{Te}_{5} \mathrm{O}_{16}$ & $\mathrm{MnTeO}_{3}$ & $\mathrm{Mn}_{3} \mathrm{TeO}_{6}$ & $\mathrm{Mn}_{2} \mathrm{Te}_{3} \mathrm{O}_{8}$ \\
\hline \multicolumn{6}{|c|}{$\mathrm{Pu} /(\mathrm{U}+\mathrm{Pu})=0.20$} \\
\hline 1.9998 & -601 & 442 & 430 & 222 & 584 \\
\hline 2.0000 & -463 & 220 & 222 & 84 & 307 \\
\hline 2.0004 & -326 & 1 & 17 & -53 & 33 \\
\hline \multicolumn{6}{|c|}{$\mathrm{Pu} /(\mathrm{U}+\mathrm{Pu})=0.25$} \\
\hline 1.9998 & -595 & 431 & 420 & 215 & 571 \\
\hline 2.0000 & -460 & 216 & 218 & 81 & 302 \\
\hline
\end{tabular}


Table 2. cont...

\begin{tabular}{|c|c|c|c|c|c|}
\hline \multirow{2}{*}{$\begin{array}{c}\mathrm{O} /(\mathbf{U}+\mathbf{P u}) \\
\text { Ratio, Fuel }\end{array}$} & \multirow{2}{*}{$\begin{array}{c}\Delta \mu\left(\mathrm{O}_{2}, \text { Fuel }\right)^{\mathrm{a}} \\
\left(\mathrm{kJ} \cdot \mathrm{mol}^{-1}\right)\end{array}$} & \multicolumn{4}{|c|}{$\Delta \mu_{\mathrm{thr}}(\mathrm{Te}) /\left(\mathrm{k} \mathrm{J} \cdot \mathrm{mol}^{-1}\right)$ for Formation of $\mathrm{Mn}_{\mathrm{z}} \mathrm{Te}_{\mathrm{x}} \mathrm{O}_{\mathrm{y}}$ on SS Clad of U-Pu Mixed Oxide Fuelled Fast Reactor } \\
\hline & & $\mathrm{Mn}_{6} \mathrm{Te}_{5} \mathrm{O}_{16}$ & $\mathrm{MnTeO}_{3}$ & $\mathrm{Mn}_{3} \mathrm{TeO}_{6}$ & $\mathrm{Mn}_{2} \mathrm{Te}_{3} \mathrm{O}_{8}$ \\
\hline \multicolumn{6}{|c|}{$\mathrm{Pu} /(\mathrm{U}+\mathrm{Pu})=0.30$} \\
\hline 1.9998 & -589 & 422 & 412 & 210 & 560 \\
\hline 2.0000 & -457 & 211 & 214 & 78 & 296 \\
\hline 2.0002 & -328 & 5 & 20 & -51 & 38 \\
\hline 2.0004 & -318 & -12 & 5 & -61 & 17 \\
\hline
\end{tabular}

${ }^{\mathrm{a}}$ The values were calculated by using the model proposed in reference [33].

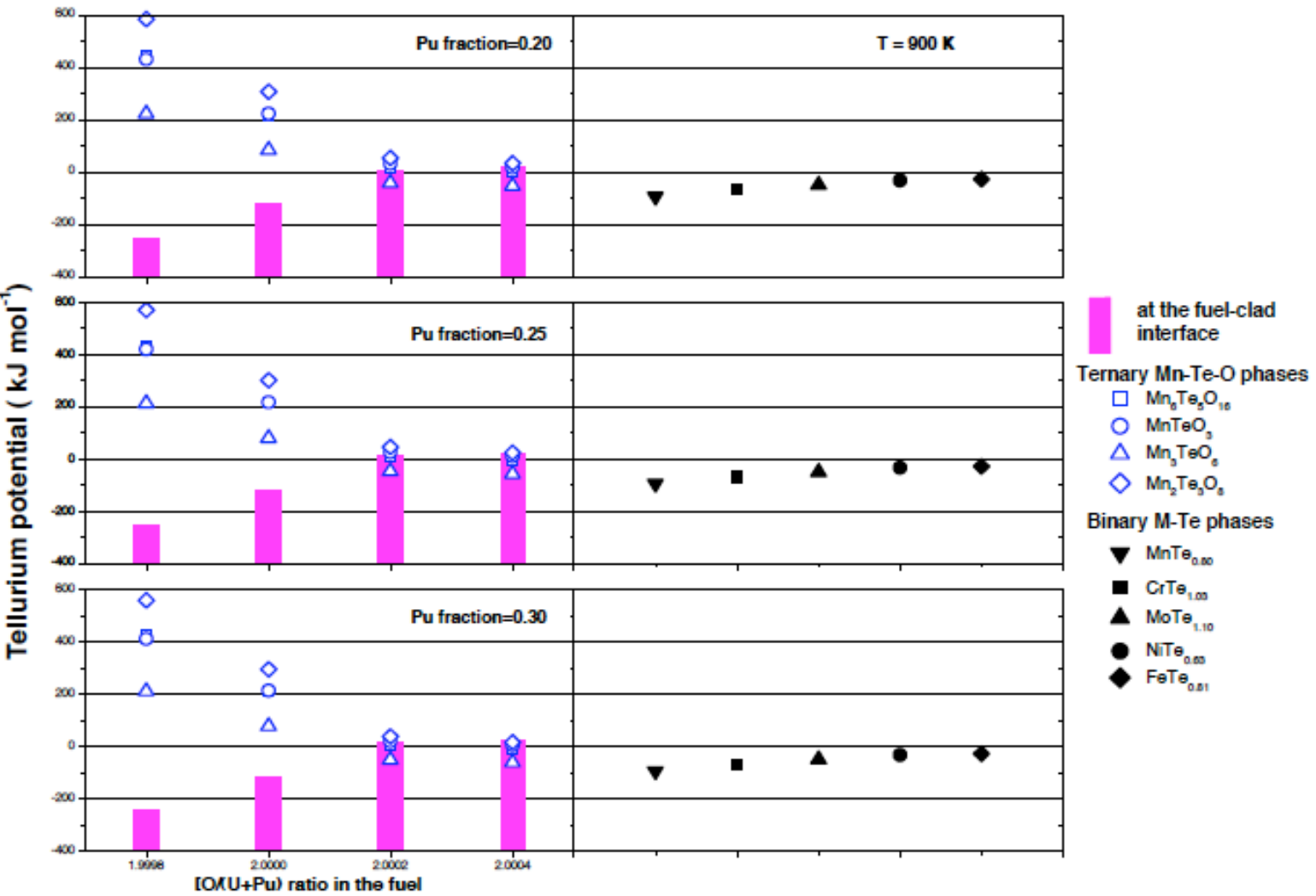

Fig. (2). Comparison of tellurium potentials at $\mathrm{T}=900 \mathrm{~K}$ (see also Tables 1 and 2): threshold $\Delta \mu_{\text {thr }}(\mathrm{Te}$ ) for formation of most metal-rich MTe phases on the SS clad of U-Pu mixed-oxide fuelled fast breeder nuclear reactors (filled symbols); available $\Delta \mu_{\mathrm{f}-\mathrm{c} \text { gap }}(\mathrm{Te})$ in the fuel-clad gap (filled bars); threshold $\Delta \mu_{\mathrm{thr}}(\mathrm{Te}$ ) for formation of Mn-Te-O phases (open symbols).

region) to 49.6 at. \% Te (the most Cr-rich two phase region). Such measurements enable determination of not only the phase boundaries, but also of thermodynamic activities at a vast number of closely spaced compositions within the homogeneity range.

\section{Vaporization Chemistry Associated with Condensed Phase Transitions}

\section{Mn-Te System}

During the course of a phase transition of a congruently vaporizing system, vaporization will become incongruent and this change from congruent to incongruent vaporization might cause unusual and counterintuitive effects. The examples shown by Viswanathan and Edwards [36] include some results on the Mn-Te system, which we published in detail already [37], but present here some salient results.
Amongst the M-Te systems we studied, it is the Mn-Te system which provided the opportunity to investigate a congruently vaporizing phase (manganese mono telluride) and also the effects associated with the phase transitions occurring in such a phase $(\alpha \leftrightarrow \beta, \beta \leftrightarrow \gamma$ and $\gamma \leftrightarrow \delta$ at 1228 $\mathrm{K}, 1293 \mathrm{~K}$, and $1323 \mathrm{~K}$, respectively).

The congruent vaporization reaction is represented by:

$\operatorname{MnTe}(\mathrm{s})=\operatorname{Mn}(\mathrm{g})+\mathrm{y} \mathrm{Te}(\mathrm{g})+(1-\mathrm{y}) / 2 \mathrm{Te}_{2}(\mathrm{~g})$

where $\mathrm{y}$ is the degree of dissociation of $\mathrm{Te}_{2}(\mathrm{~g})$. The Mn-toTe atomic ratio in the vapor phase during congruent vaporization was $\sim 0.6$.

Every temperature change triggered a change in the vaporization behavior: in general, the vapor phase became relatively richer in $\mathrm{Mn}$ in the increasing temperature 


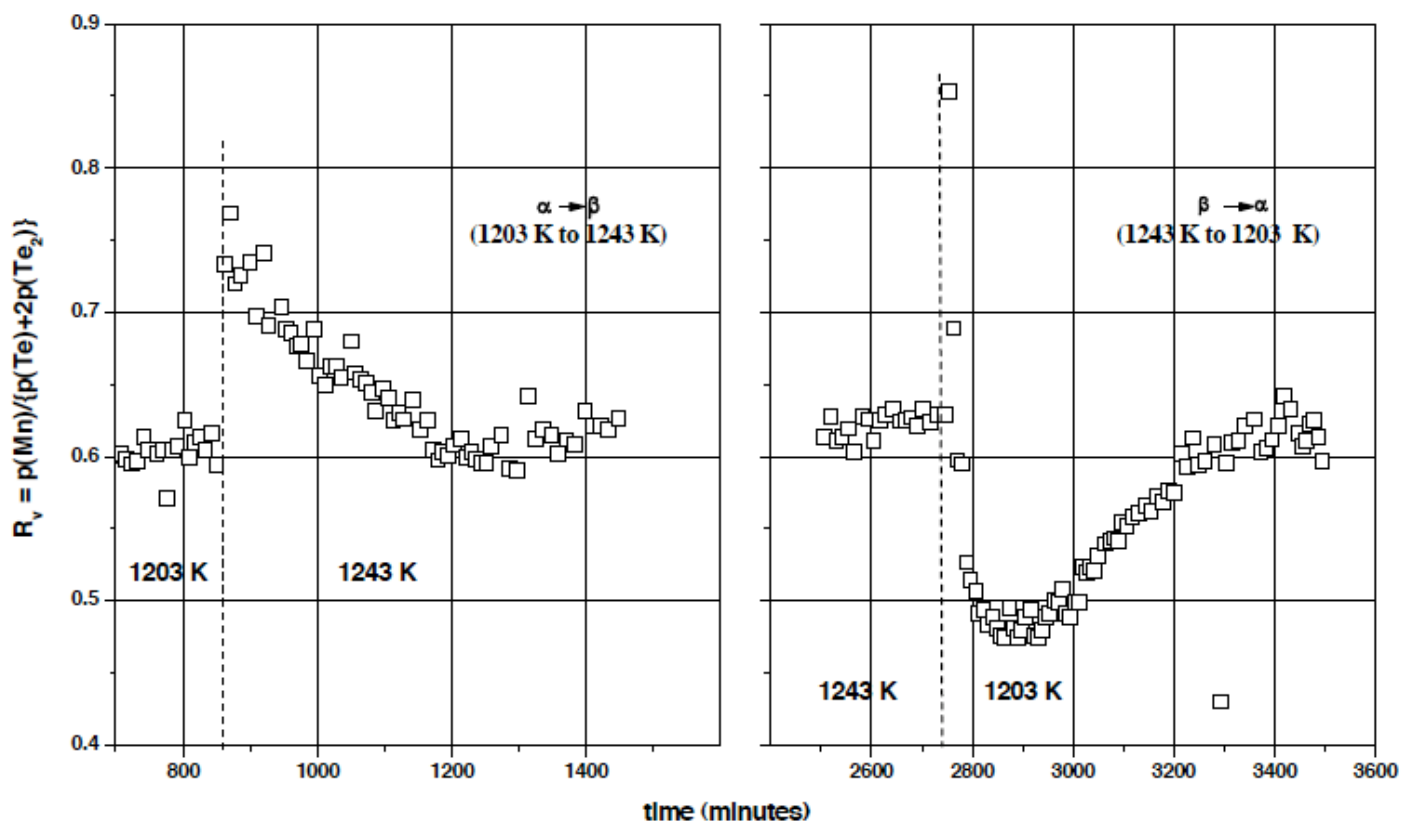

Fig. (3). Vapor phase composition (Mn-to-Te atom fraction ratio) during congruent vaporization and during phase transition in manganese mono telluride. $\alpha \rightarrow \beta$ transition as T was increased from $1203 \mathrm{k}$ to $1243 \mathrm{~K}$. $\beta \rightarrow \alpha$ transition as T was decreased from $1243 \mathrm{~K}$ to $1203 \mathrm{~K}$.

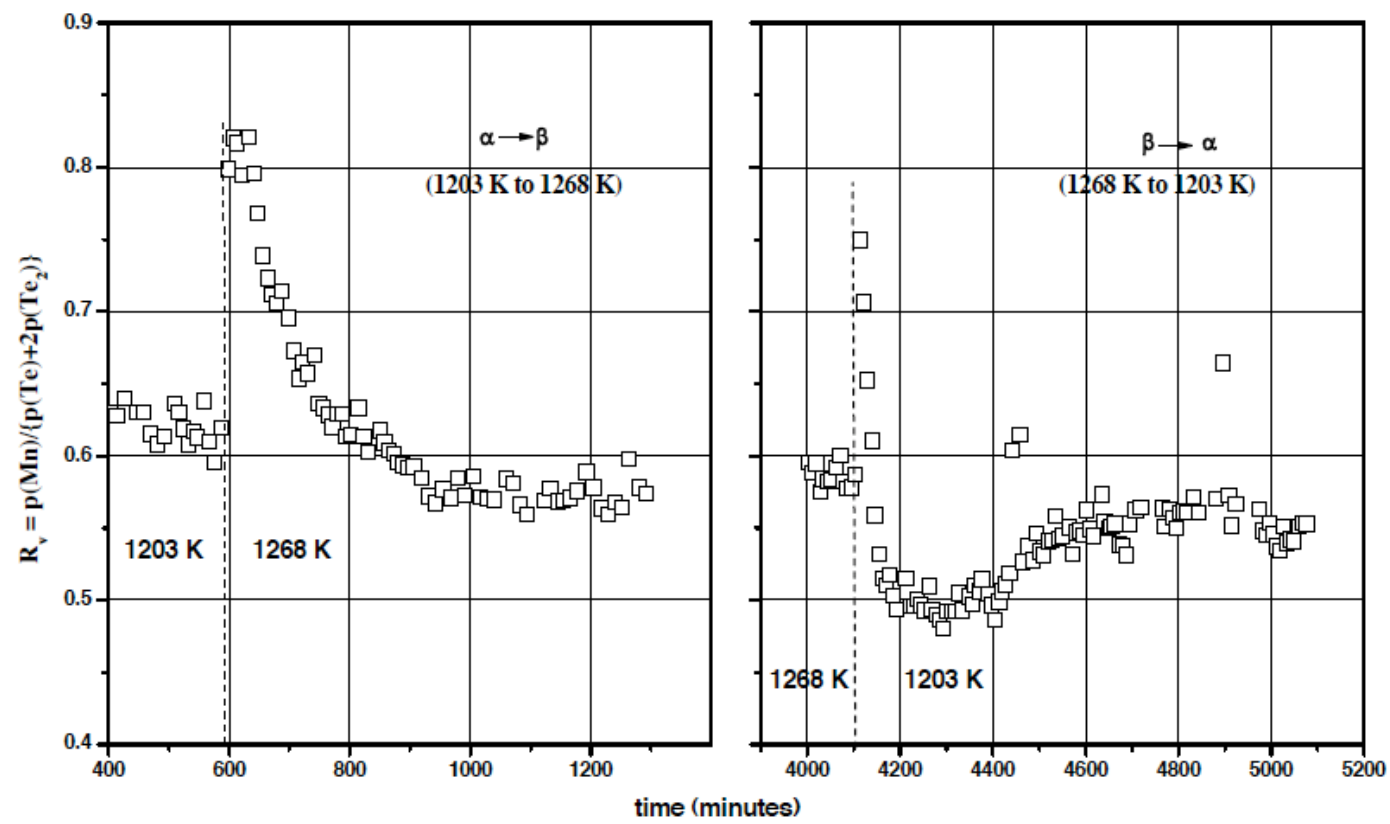

Fig. (4). Vapor phase composition (Mn-to-Te atom fraction ratio) during congruent vaporization and during phase transition in manganese mono telluride. $\alpha \rightarrow \beta$ transition as T was increased from $1203 \mathrm{~K}$ to $1268 \mathrm{~K}$. $\beta \rightarrow \alpha$ transition as T was decreased from $1268 \mathrm{~K}$ to $1203 \mathrm{~K}$.

direction and became relatively richer in Te in the decreasing temperature direction. This indicated a monotonic drift with temperature in the congruently effusing composition (CEC), but the precision with which the values of the CEC could be computed was not good enough to support the inference quantitatively. The monotonic change in the CEC with temperature was distinguishable from the discontinuous change in the CEC associated with the condensed phase transition. Amongst the three known phase transitions in $\operatorname{MnTe}(\mathrm{s})$, only the $(\alpha \leftrightarrow \beta)$ phase transition gave rise to a definite period of time during which the vapor phase composition was invariant with time and different from that corresponding to the CEC of the either phase.
Fig. (3) shows the plot of $R_{v}=p(M n) /\left[\left(p(T e)+2 p\left(T_{2}\right)\right]\right.$, the Mn-to-Te ratio in the vapor phase, as the temperature was cycled between $1203 \mathrm{~K}$ and $1243 \mathrm{~K}$. The value of $R_{v}$ was $\sim 0.75$ at $1243 \mathrm{~K}$ during the incongruent vaporization involving $\alpha \rightarrow \beta$ transformation that lasted $\sim 45$ minutes while it was $\sim 0.48$ at $1203 \mathrm{~K}$ during the incongruent vaporization involving $\beta \rightarrow \alpha$ that lasted nearly 200 minutes. The value of $R_{v}$ during congruent vaporization of $\alpha$ at 1203 $\mathrm{K}$ or $\beta$ at $1243 \mathrm{~K}$ was $\sim 0.6$. If the measurements were not performed continuously or if only the data corresponding to eventual congruent vaporization were considered important, the effect of the condensed phase transition would have escaped the attention of the researcher. Fig. (4) shows the 


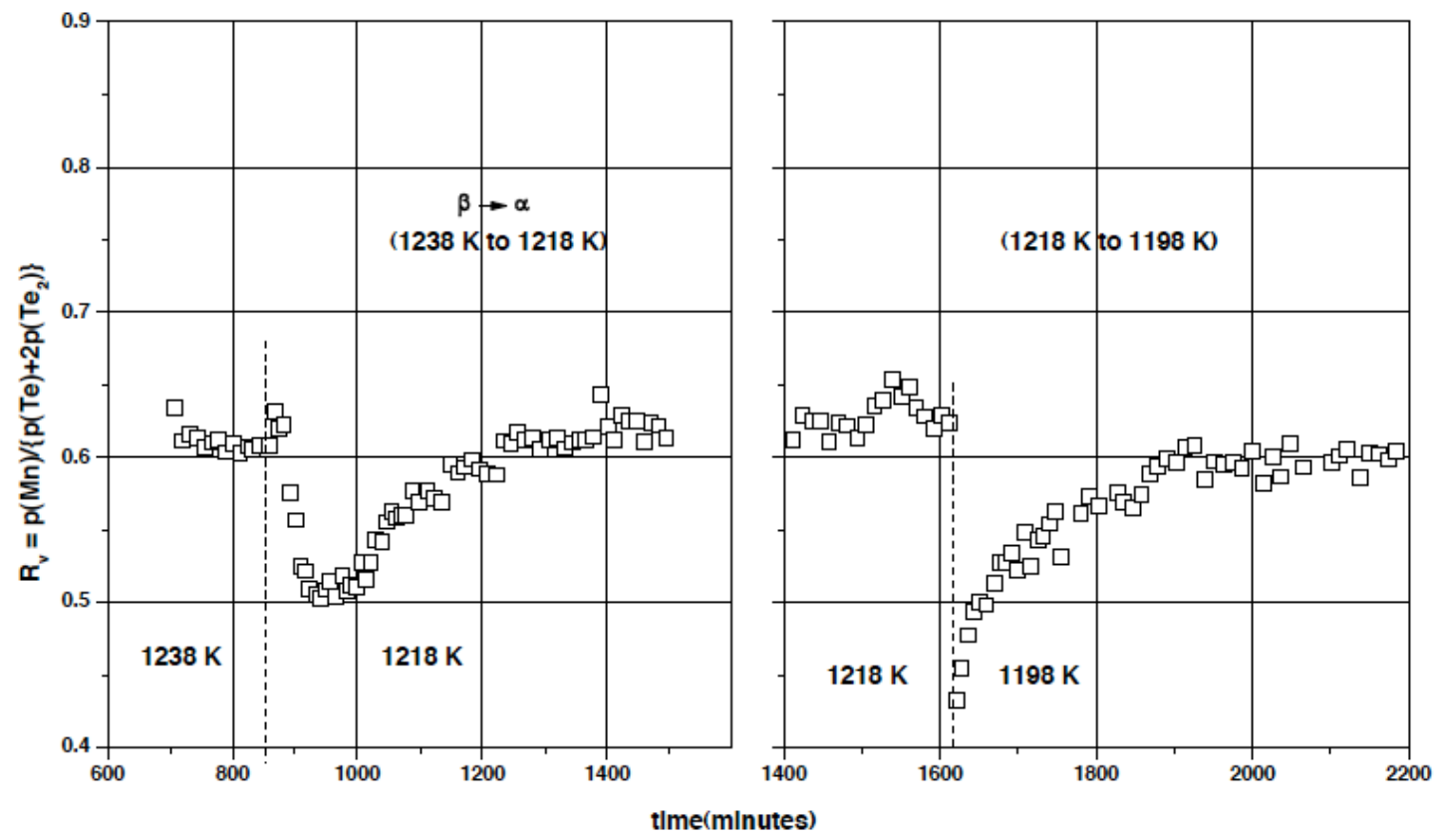

Fig. (5). Effect of $20 \mathrm{~K}$ change in temperature involving $\beta \rightarrow \alpha$ phase transition (1238 K to $1208 \mathrm{~K}$ ) and CEC adjustment within the $\alpha$ phase of manganese mono telluride (1208 K to $1198 \mathrm{~K}$ ).

results of another experiment in which the temperature was cycled between $1203 \mathrm{~K}$ and $1268 \mathrm{~K}$. The value of $\mathrm{R}_{\mathrm{v}}$ during the $\alpha \rightarrow \beta$ transformation at $1268 \mathrm{~K}$ was slightly higher than that obtained at $1243 \mathrm{~K}$, but the duration was relatively smaller. The duration of $\alpha \rightarrow \beta$ transformation is shorter than that of $\beta \rightarrow \alpha$ transformation because, the vaporization rate is higher at higher temperatures of $1243 \mathrm{~K}$ or $1268 \mathrm{~K}$, and consequently the CEC of the $\beta$ phase is reached relatively more quickly by losing the excess manganese. Fig. (5) shows the difference between the effect of temperature change of $20 \mathrm{~K}$ in two cases, one which involved $\beta \rightarrow \alpha$ phase transition $(1238 \mathrm{~K}$ to $1218 \mathrm{~K})$, and the other which involved just rearrangement of the CEC within the $\alpha$ phase $(1218 \mathrm{~K}$ to $1198 \mathrm{~K})$. Although in both cases, the temperature change caused Te-enrichment in the vapor (decrease in the value of $R_{v}$ from 0.6), the value of $R_{v}$ remained stable at the low value of $\sim 0.5$ for $\sim 80$ minutes in the first case before increasing monotonically to 0.6 , whereas the monotonic increase in $\mathrm{R}_{\mathrm{V}}$ was immediate in the second case. The effects associated with the other two phase transitions $\beta \leftrightarrow \gamma$ or $\gamma \leftrightarrow$ $\delta$ were not so well noticeable as that with the $\alpha \leftrightarrow \beta$ phase transition. The CEC of all the four phases were all close to 50 at. $\%$ Te [37]: $49.2 \pm 1.1$ at. $\%$ Te $(\alpha), 49.5 \pm 1.1$ at. $\%$ Te $(\beta), 49.7 \pm 0.1$ at. $\% \mathrm{Te}(\gamma)$, and 50.3 at. $\% \mathrm{Te}(\delta)$.

The results obtained in our KEMS study of Mn-Te system provided significant evidence to the power of KEMS towards providing a better understanding of the vaporization chemistry associated with the condensed phase transitions. There are many systems which might facilitate such studies, but, it would require very involved measurements to notice the effects because often, the effects may not be significant.

\section{Mn-Te-O System}

Our KEMS study [31,32] of $(\mathrm{MnO})_{\mathrm{x}}\left(\mathrm{TeO}_{2}\right)_{1-\mathrm{x}}(\mathrm{x}=0.54$, $0.50,0.43$, and 0.37 ) showed that on prolonged vaporization at $\mathrm{T}=950 \mathrm{~K}$, all samples reached a quasi congruently vaporizing state with the effusate consisting of only $\mathrm{Te}-$ and
$\mathrm{O}-$ bearing vapor species $\left(\mathrm{Te}_{2}, \mathrm{TeO}, \mathrm{TeO}_{2}\right.$, and $\left.\mathrm{O}_{2}\right)$ and having an atomic ratio of $\mathrm{Te} / \mathrm{O} \approx 2 / 3$. The residue in all the cases were a two phase mixture of $\left(\mathrm{MnTeO}_{3}+\mathrm{Mn}_{3} \mathrm{TeO}_{6}\right)$, indicating that the sample composition during the congruent vaporization corresponded to that along the $\mathrm{MnTeO}_{3}-$ $\mathrm{Mn}_{3} \mathrm{TeO}_{6}$ binary line. That is, $(\mathrm{Te}+\mathrm{Mn}) / \mathrm{O}=2 / 3$. The term quasi congruent vaporization is used here because it really is an incongruent vaporization involving three phases (two condensed phases plus one vapor phase) and is univariant (or invariant at a constant temperature; $\mathrm{T}=950 \mathrm{~K}$ ) due to equality of the ratio $(\mathrm{Mn}+\mathrm{Te}) / \mathrm{O}$ in the condensed and vapor phase, and not due to the equality of the atom fractions of the three elements $\mathrm{Mn}, \mathrm{Te}, \mathrm{O}$.

In experiments with the first two samples which contained three phases $\mathrm{Mn}_{2} \mathrm{Te}_{3} \mathrm{O}_{8}, \mathrm{MnTeO}_{3}$, and $\mathrm{Mn}_{3} \mathrm{TeO}_{6}$, the disappearance of the $\mathrm{Mn}_{2} \mathrm{Te}_{3} \mathrm{O}_{8}$ phase occurred rather quickly to give rise to the univariant three-phase equilibrium of $\left(\mathrm{MnTeO}_{3}+\mathrm{Mn}_{3} \mathrm{TeO}_{6}+\mathrm{v}\right)$. With the third sample which contained relatively larger amount of $\mathrm{Mn}_{2} \mathrm{Te}_{3} \mathrm{O}_{8}$, the attainment of univariant three-phase equilibrium took longer time. With the fourth sample, which had two phases, $\mathrm{Mn}_{2} \mathrm{Te}_{3} \mathrm{O}_{8}$ and $\mathrm{MnTe}_{2} \mathrm{O}_{5}$, both lying on the $\mathrm{MnO}-\mathrm{TeO}_{2}$ binary line, it appeared that the sample first entered into the two phase region of $\left(\mathrm{Mn}_{2} \mathrm{Te}_{3} \mathrm{O}_{8}+\mathrm{MnTeO}_{3}\right)$ or the threephase region of $\left(\mathrm{Mn}_{2} \mathrm{Te}_{3} \mathrm{O}_{8}+\mathrm{MnTeO}_{3}+\mathrm{Mn}_{3} \mathrm{TeO}_{6}\right)$ before following the same path as that of the other samples. Invariably, the eventual transition to quasi congruent vaporization equilibrium involving $\left(\mathrm{MnTeO}_{3}+\mathrm{Mn}_{3} \mathrm{TeO}_{6}+\right.$ v) was accompanied by an anomalous vaporization behavior with respect to effusion of $\mathrm{Te}_{2}(\mathrm{~g})$. Fig. (6) shows how $\mathrm{Te}_{2}$, $\mathrm{TeO}$, and $\mathrm{TeO}_{2}$ varied during the above mentioned transition: while the partial pressures of $\mathrm{TeO}_{2}(\mathrm{~g})$ and $\mathrm{TeO}(\mathrm{g})$ decreased monotonically to settle at lower values, that of $\mathrm{Te}_{2}(\mathrm{~g})$ decreased initially, and after reaching a minimum increased again to settle at a pressure slightly higher than that corresponding to the initial four phase equilibrium. 


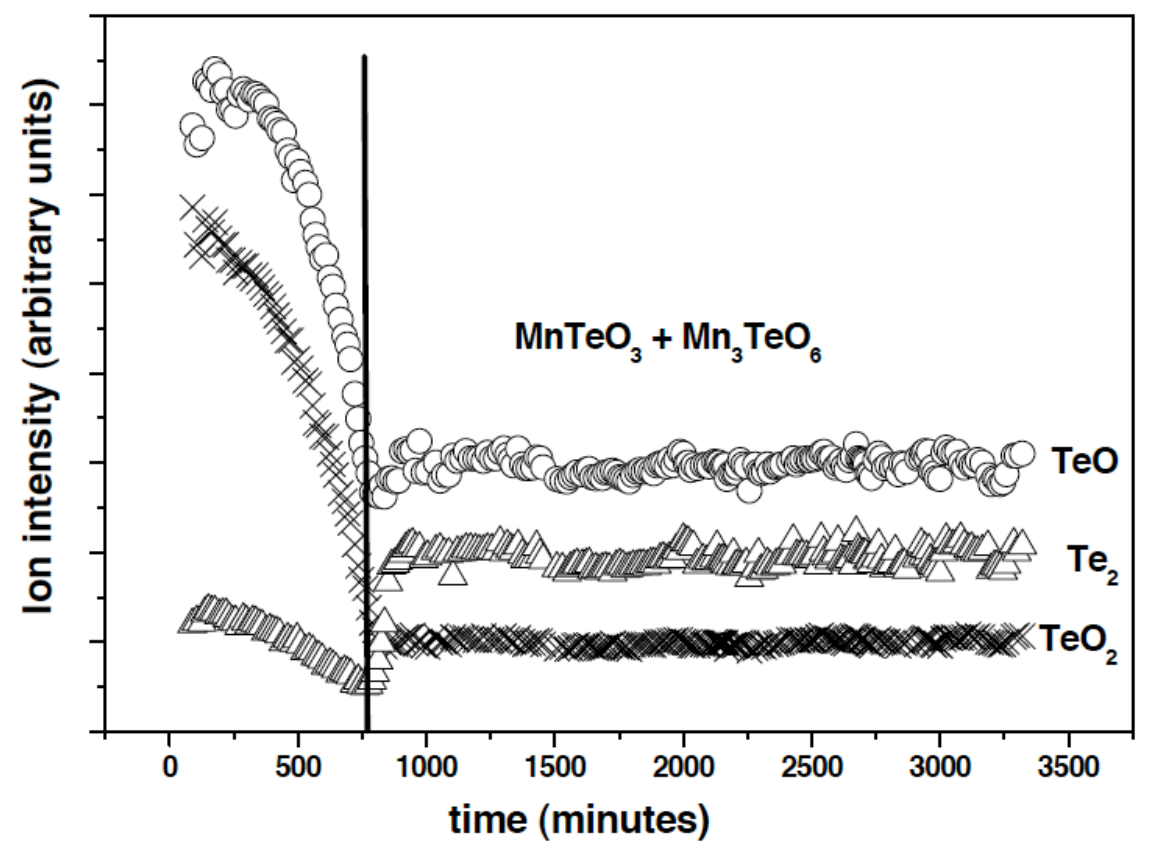

Fig. (6). Anomalous vaporization behavior (with regard to the species $\mathrm{Te}_{2}$ ) caused by the onset of quasi congruent vaporization in the Mn-TeO system. $\mathrm{T}=950 \mathrm{~K} . \mathrm{Te}_{2}(\mathrm{~g}): \Delta ; \mathrm{TeO}(\mathrm{g}): \circ ; \mathrm{TeO}_{2}(\mathrm{~g}): \times$.

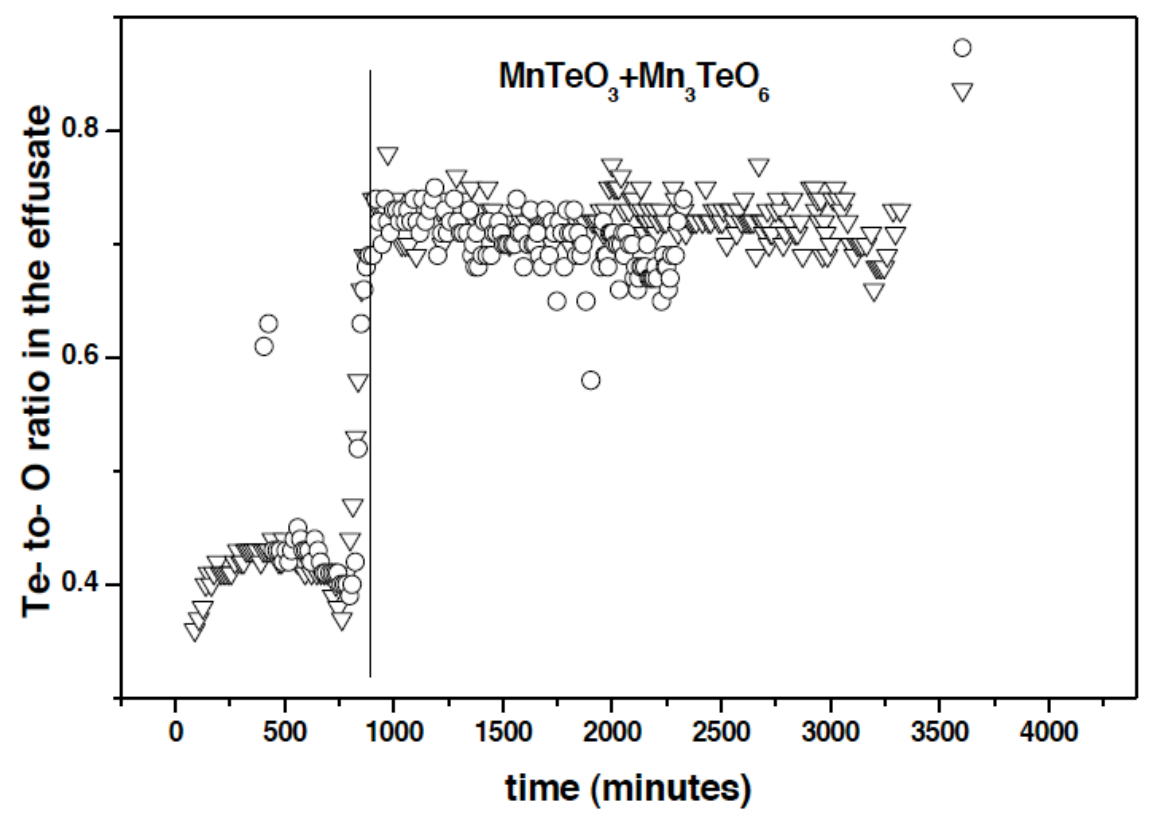

Fig. (7). Change in the Te-to-O atomic ratio in the effusate caused by the onset of quasi congruent vaporization in the Mn-Te-O system. $\mathrm{T}=950 \mathrm{~K}$.

The possible reactions that lead to the univariantly vaporizing two-phase mixture are:

$$
\begin{aligned}
& 3 \mathrm{MnTeO}_{3}(\mathrm{~s})=\mathrm{Mn}_{3} \mathrm{TeO}_{6}(\mathrm{~s})+\mathrm{TeO}(\mathrm{g})+\mathrm{TeO}_{2}(\mathrm{~g}) \\
& 6 \mathrm{MnTeO}_{3}(\mathrm{~s})=2 \mathrm{Mn}_{3} \mathrm{TeO}_{6}(\mathrm{~s})+2 \mathrm{Te}_{2}(\mathrm{~g})+3 \mathrm{O}_{2}(\mathrm{~g})
\end{aligned}
$$

The Te-to-O atomic ratio in the effusate $\left(\mathrm{R}_{\text {effusate }}\right)$ should be $2 / 3$, if the reactions 20 and 21 were to be univariant, As can be seen from Fig. (7), the $\mathrm{R}_{\text {effusate }}$ value initially was around 0.5 , and then increased to 0.7 before remaining constant until the end in each experiment, thus providing the proof for occurrence of an univariant vaporization of the two phase mixture $\left(\mathrm{MnTeO}_{3}+\mathrm{Mn}_{3} \mathrm{TeO}_{6}\right)$. What makes this quasi congruent univariant equilibrium uncommon is that the two ternary condensed phases $\mathrm{MnTeO}_{3}$ and $\mathrm{Mn}_{3} \mathrm{TeO}_{6}$ cannot be placed on any one single pseudo binary line constituted by the binary oxides of $\mathrm{Mn}$ and Te. For instance, the phase $\mathrm{MnTeO}_{3}$ can be placed on the $\mathrm{MnO}-\mathrm{TeO}_{2}$ binary line (as $\mathrm{MnO} . \mathrm{TeO}_{2}$ ), where as the phase $\mathrm{Mn}_{3} \mathrm{TeO}_{6}$ can be placed on either the $\mathrm{MnO}-\mathrm{TeO}_{3}$ binary line (as $3 \mathrm{MnO}^{-\mathrm{TeO}_{3}}$ ) or on the $\mathrm{Mn}_{3} \mathrm{O}_{4}-\mathrm{TeO}_{2}$ binary line (as $\mathrm{Mn}_{3} \mathrm{O}_{4} \cdot \mathrm{TeO}_{2}$ ). To our knowledge, experimental verification of an univariant equilibrium of the type observed by us has not been reported previously, although existence of the 'partial congruent vaporization' corresponding to $\left(\mathrm{Si}+\mathrm{Si}_{2} \mathrm{~N}_{2} \mathrm{O}+\right.$ vapor) in the $\mathrm{Si}-$ $\mathrm{N}-\mathrm{O}$ system was predicted by Rocabois et al. [38]. However, one of the condensed phases is an element in this case unlike in our study where both condensed phases are ternary phases. 
One possible explanation for the observation that all samples eventually tend to reach the two-phase field of $\left(\mathrm{MnTeO}_{3}+\mathrm{Mn}_{3} \mathrm{TeO}_{6}\right)$ is attributed to the existence of a $\mathrm{Te}(\mathrm{IV}) \leftrightarrow \mathrm{Te}(\mathrm{VI})$ equilibrium in the condensed phase or the preference of tellurium to remain in $\mathrm{Te}(\mathrm{VI})$. The movement of sample composition along the $\mathrm{MnO}-\mathrm{TeO}_{2}$ binary line through loss of $\mathrm{TeO}_{2}$ units (i.e. Te-to-O ratio in the effusate $=1 / 2$ rather than 2/3) would retain tellurium as Te(IV). But upon reaching $\mathrm{MnTeO}_{3},\left(\mathrm{MnO} / \mathrm{TeO}_{2}=1\right)$, it appears as though the condensed phase does not want to move further on the same pseudo-binary line, but instead moves along the $\mathrm{MnTeO}_{3}-\mathrm{Mn}_{3} \mathrm{TeO}_{6}$ line. While doing so, the vapor phase composition has to rearrange such that ultimately, the stoichiometric compositions of $\mathrm{MnTeO}_{3}$ and $\mathrm{Mn}_{3} \mathrm{TeO}_{6}$ appropriate for the quasi congruent equilibrium are reached. Perhaps, this is the explanation that can be offered for the anomalous vaporization behavior depicted in Fig. (7).

\section{SUMMARY}

We have reviewed the Knudsen effusion mass spectrometric studies performed by us to discuss how the vaporization studies can yield information of both practical and fundamental importance. The vaporization studies on M$\mathrm{Te}$ systems and $\mathrm{Mn}-\mathrm{Te}-\mathrm{O}$ system provided the actual values of tellurium potentials required for their formation on SS clad of fast breeder nuclear reactors. Thaey also provided information on the composition range of existence of nonstoichiometric telluride phases, which is of fundamental interest to solid state chemistry. The study of vaporization behavior associated with condensed phase transitions in the $\mathrm{Mn}-\mathrm{Te}$ and $\mathrm{Mn}-\mathrm{Te}-\mathrm{O}$ systems revealed that KEMS can be effectively utilized to investigate the link between the vaporization chemistry and condensed phase chemistry.

\section{CONFLICT OF INTEREST}

The authors confirm that this article content has no conflicts of interest.

\section{ACKNOWLEDGEMENT}

Declared none.

\section{REFERENCES}

[1] W. A. Chupka and M. G. Inghram, "Investigation of the heat of vaporization of carbon", The Journal of Chemical Physics, vol. 21, pp. 371-372, 1953.

[2] L. Brewer, "Principles of high temperature chemistry" In: Proceedings of the R. A. Welch Foundation Conference on Chemical Research, Houston: Texas, vol VI, 1962, pp. 47-92.

[3] M. G. Inghram and J. Drowart, Mass Spectrometry Applied to High Temperature Chemistry in High Temperature Technology, McGraw Hill: New York, 1960, pp. 219-240.

[4] J. Drowart, Mass Spectrometry, Proc. Int. School mass spectrom, J. Marsel, Ed, Stefan Institute: Lubljana, 1969, 1971. pp. 187-242.

[5] J. Drowart, Advances in Mass Spectrometry, J. F. J. Todd, Ed., John Wiley \& Sons: Chichester, 1986, p.185.

[6] R. T. Grimley, The characterization of High-Temperature Vapors, J.L. Margrave, Ed, Wiley: New York, Chapter 8; 1967, pp. 195243.

[7] K. A. Gingerich, Molecular Species in High Temperature vaporization, Current Topics in Materials Science; E. Kaldis, Ed, vol. 6, North Publishing Co: Amsterdam, North Holland, 1980, pp. 345-462.

[8] K. Hilpert, Chemistry of Inorganic Vapors, Structure and Bonding, vol.73, Springer-Verlag: Berlin, 1990, pp. 97-198.
[9] J. Drowart, C. Chatillon, J. W. Hastie, and D. W. Bonnel, “ High temperature mass spectrometry: Instrumental techniques, ionisation, cross-sections, pressure measurements and thermodynamic data", Pure and Applied Chemistry, vol. 77, pp. 683-737, 2005.

[10] M. G. Adamson, E. A. Aitken, and T. B. Lindemer, "Chemical thermodynamics of $\mathrm{Cs} \& \mathrm{Te}$ fission product interactions in irradiated LMFBR mixed oxide fuel pins", Journal of Nuclear Materials, vol. 130, pp. 375-392, 1985.

[11] J. A. Roberts Jr. and A. W. Searcy, "Anomalous temperature dependence for a partial vapor pressure", Science, vol. 196, pp. 525-527, 1977.

[12] A. S. Gates and J. G. Edwards, "Vaporization chemistry, kinetics and thermodynamics of compounds in the manganese monosulfideGallium sesquisulfide Systems", The Journal of Physical Chemistry, vol. 84, pp. 3263-3270, 1980.

[13] J. G. Edwards and J. S. Starzynski, "Differential vapor pressures in the $\mathrm{Ga}_{2} \mathrm{~S}_{3}-\mathrm{MnGa}_{2} \mathrm{~S}_{4} / \mathrm{Mn}_{3} \mathrm{Ga}_{2} \mathrm{~S}_{6}$ System and the Vapor pressure of Gallium sulfide", High Temperature Science, vol. 14, pp. 63-70, 1981.

[14] J. G. Edwards and R. S. Uram, "Multiple equilibrium states in effusion cells: catastrophic phase transitions," The Journal of Physical Chemistry, vol. 96, pp. 8561-68, 1992.

[15] J. G. Edwards, "Anomalous phenomenons in effusion studies of two components systems", High Temperature Science, vol. 32, pp. 37-50, 1991.

[16] J. G. Edwards, "Triple points as Pernts", Thermochimica Acta, vol. 210, pp. 273-280, 1992.

[17] J. G. Edwards and H. F. Franzen, "Condensed phase transitions in binary systems during dynamic vaporization experiments: Effusion and transpiration", The Journal of Physical Chemistry, vol. 99, pp. 4779-4786, 1995.

[18] J. G. Edwards, M.P. Burckel, K. Hilpert, and D. Kath, "Mass spectrometric observation of a condensed-phase transition during effusion of gallium sesquisulfide", Thermochimica Acta, vol. 297, pp. 177-185, 1997.

[19] R. Viswanathan and J. G. Edwards, "Condensed phase transitions during effusion of gallium selenide", The Journal of Physical Chemistry, B vol. 102, pp. 2419-2426, 1998.

[20] B. Saha, R. Viswanathan, M. Sai Baba, D. Darwin Albert Raj, R. Balasubramanian, D. Karunasagar, and C.K. Mathews, " High temperature mass-spectrometric studies of $\mathrm{Te}(\mathrm{s}), \mathrm{FeTe}_{0.9}(\mathrm{~s})$ ", The Journal of Nuclear Materials, vol. 130, pp. 316-325, 1985.

[21] R. Viswanathan, M. Sai Baba, D. Darwin Albert Raj, R. Balasubramanian, B. Saha, and C.K. Mathews, "Thermo chemistry of metal-rich chromium telluride and its role in fuel-clad chemical interactions", The Journal of Nuclear Materials, vol. 167, pp. 94104, 1989.

[22] R. Viswanathan, M. Sai Baba, D. Darwin Albert Raj, R. Balasubramanian, B. Saha, and C. K. Mathews, "Vaporisation thermodynamics of the nickel-rich phases in the Ni-Te binary system - A high temperature mass spectrometric study", The Journal of Nuclear Materials, vol. 149, pp. 302-311, 1987.

[23] R. Viswanathan, R. Balasubramanian and C. K. Mathews, "Vaporisation thermodynamics of the metal-rich molybdenum telluride $\mathrm{Mo}_{3} \mathrm{Te}_{4}$ : a high temperture mass spectrometric study" Journal of Chemical Thermodynamic, Vol. 21, pp. 1183-1191, 1989.

[24] M.Sai Baba, T. S. Lakshmi Narasimhan, R. Balasubramanian, and C.K. Mathews, "Thermochemistry of metal-rich manganese telluride and its role in fuel-clad interactions", The Journal of Nuclear Materials, vol. 201, pp. 147-155, 1993.

[25] R. Viswanathan, M. Sai Baba, D. Darwin Albert Raj, R. Balasubramanian, T. S. Lakshmi Narasimhan, and C. K. Mathews, "A mass spectrometric study of the dissociation of the gaseous diatomic tellurium molecule", Spectrochimica Acta, vol. 49B, pp. 243-250, 1994.

[26] M. Sai Baba, R. Viswanathan, D. Darwin Albert Raj, R. Balasubramanian, B. Saha, and C.K. Mathews, "Vaporisation thermodynamics of (iron+tellurium) - a high temperature mass spectrometric study", The Journal of Chemical Thermodynamics, vol. 20, pp. 1157-1173, 1988.

[27] K. O. Klepp and K. L. Komarek, "Transition metal-chalcogen systems, III. The System Ni- Te", Monatshefte for Chemicie. vol. 103, pp. 934-946, 1972. 
[28] R. Viswanathan, D. Darwin Albert Raj, T. S. Lakshmi Narasimhan, R. Balasubramanian, and C. K. Mathews, "Study of (molybdenum + tellurium) by Knudsen-effusion mass spectrometry", The Journal of Chemical Thermodynamics, vol. 25, pp. 533- 547, 1993.

[29] A. M. Azad, O. M. Sreedharan, and J. B. Gnanamoorthy, "A novel determination of thermodynamic activities of metals in an AISI316 stainless steel by a metastable e.m.f. method", Journal of Nuclear Materials, vol. 144, pp. 94-104, 1987.

[30] T. S. Lakshmi Narasimhan, M. Sai Baba, S. Nalini, and R. Viswanathan, " A ternary phase diagram of the $\mathrm{Mn}-\mathrm{Te}-\mathrm{O}$ system at 950 K”, Thermochimica Acta, vol. 410, pp. 149-159, 2004.

[31] T. S. Lakshmi Narasimhan, M. Sai Baba, and R. Viswanathan, "Univariant three-phase and four-phase vaporization equilibria in the ternary $\mathrm{Mn}-\mathrm{Te}-\mathrm{O}$ system: A high temperature mass spectrometric study of binary $\left.\mathrm{x}(\mathrm{MnO})+(1-\mathrm{x}) \mathrm{TeO}_{2}\right)$ with $\mathrm{x} \geq 0.5$," The Journal of Physical Chemistry, B vol. 106, pp. 6762-6770, 2002.

[32] T. S. Lakshmi Narasimhan, M. Sai Baba, and R. Viswanathan, "Vaporization termodynamic studies by high temperature mass spectrometry on some three-phase regions over the $\mathrm{MnO}-\mathrm{TeO}_{2}$ binary line in the Mn-Te-O ternary system", The Journal of Physical Chemistry, A vol. 110, pp. 13705-13711, 2006.

[33] M. V. Krishnaiah and P. Sriramurti, "Computational model for the oxygen potentials of mixed uranium-plutonium oxide", Journal of the American Ceramic Society, vol. 67, pp. 568-571, 1984.
[34] R.Viswanathan, M. Sai Baba, T. S. Lakshmi Narasimhan, R. Balasubramanian, D. Darwin Albert Raj, and C. K. Mathews, "Homogeneity ranges and thermodynamic properties of the Te-rich phases in the Cr-Te system", The Journal of Alloys and Compounds, vol. 206, pp. 201-210, 1994.

[35] T. S. Lakshmi Narasimhan, M. Sai Baba, R. Balasubramanian, S.Nalini, and R. Viswanathan, "Vaporization studies on (manganese + tellurium) with $\mathrm{x}(\mathrm{Te})>0.5$ by Knudsen effusion mass spectrometry", The Journal of Chemical Thermodynamics, vol. 34, pp. 103-117, 2002.

[36] R Viswanathan and J G Edwards, "Effects of condensed-phase transitions in congruently vaporizing systems", The Journal of Chemical Thermodynamics, vol. 34, pp. 163-172, 2002.

[37] T. S. Lakshmi Narasimhan, $R$ Viswanathan, and $R$ Balasubramanian, "Congruent vaporization of manganese monotelluride and the effect of phase transitions : a high temperature mass spectrometric study", The Journal of Physical Chemistry, B vol. 102,pp. 10586- 10595, 1998.

[38] P. Rocabois, C. Chatillon, and C. Bernard, "High-temperature analysis of the thermal degradation of silicon based materials II: Ternary Si-C-O, Si-N-O and Si-C-N Compounds", High Temperature - High Page Rank, vol.31, pp. 433-454, 1999.

(C) Narasimhan and Viswanathan; Licensee Bentham Open.

This is an open access article licensed under the terms of the Creative Commons Attribution Non-Commercial License (http://creativecommons.org/licenses/ by-nc/3.0/) which permits unrestricted, non-commercial use, distribution and reproduction in any medium, provided the work is properly cited. 